\title{
Optimization of Process Parameters for the Carbonization of Flamboyant Pod Bark (Delonix Regia)
}

\author{
Aremu, M. $O$. \\ Alade, A. $O$. \\ Araromi, D. $O$. \\ Bello, $A$.
}

Department of Chemical Engineering, Ladoke Akintola University of

Technology, Ogbomoso, Nigeria

doi: 10.19044/esj.2017.v13n24p165 URL:http://dx.doi.org/10.19044/esj.2017.v13n24p165

\begin{abstract}
This study investigates the carbonization of flamboyant pod bark (FPB) for the purpose of production of effective activated carbon from the agricultural residue. Central Composite Design (CCD) under the Response Surface Methodology was employed to combine the selected process parameters [Temperature $\left(300-600{ }^{\circ} \mathrm{C}\right)$ and Time $(30-65$ mins $\left.)\right]$ for the carbonization. FPB were collected within the fields of Ladoke Akintola University of Technology, Ogbomoso, mechanically cracked, crushed, washed with distilled water and sun-dried for seven days before eventually subjecting to carbonization, after which the resultant yields were determined and the statistical analysis was evaluated. The maximum $(45.45 \%)$ and minimum $(11.82 \%)$ yields were obtained at Run $1\left(300^{\circ} \mathrm{C} / 30 \mathrm{mins}\right)$ and Run $11\left(600^{\circ} \mathrm{C} / 65 \mathrm{mins}\right)$. The quadratic model equation is given as Yield = $23.27-3.48 A-4.38 B-2.81 A^{2}+0.19 B^{2}+0.11 A B$ and the $\mathrm{R}^{2}$ value for the model equation is 0.9705 while the adjusted as well as predicted $R^{2}$ values are 0.9459 and 0.8578 , respectively. The numerical optimization by the Design Expert (6.0.8) software suggested minimum yield of 12.89\%, (600 ${ }^{0} \mathrm{C} / 65$ mins) at desirability of 0.941 . This research has indicated the suitability of using CCD for the optimization of process parameters for the carbonization of Flamboyant Pod Bark.
\end{abstract}

Keywords: Carbonization, Central Composite Design, Flamboyant Pod Bark, Yields 


\section{Introduction}

Activated carbon (AC) is a solid carbonaceous material with a porous structure (Sugumaran et al., 2012). Activated carbon of high quality will have extended surface area, microporous structures, high adsorption capacity and high degree of surface reactivity (Hameed et al., 2009). Activated carbon produced from high carbon content agricultural residues such as corn cob, coconut shell, grain sorghum, coir pith, walnut shell, rice bran, oil palm shell, flamboyant pod bark and sugarcane bagasses were found to have good adsorbent properties which makes it suitable for treatment of wastewater and adsorption of hazardous gases (Tsai et al., 1997; Hu and Srinivasan, 1999; Diao et al., 2002; Ash et al., 2006; Martinez et al., 2006; Suzuki et al., 2007; Tan et al., 2007; Hu et al., 2009; Sugumaran and Seshadri, 2009).

Several treatment methods such as adsorption, ion exchange, reverse osmosis, chemical oxidation, precipitation, distillation, solvent extraction and bio-remediation are available for the removal of organic and inorganic pollutants from wastewater. Among the various methods, adsorption process has been found to be superior compared to other methods for the removal of colour, odour, organic and inorganic pollutants from wastewater (Krishnaiah et al., 2013). Adsorption is a process that occurs when a gas or liquid solute accumulates on the surface of a solid or liquid which is known as adsorbent, forming a film of molecules or atoms which is called adsorbate. It differs from absorption in which a gas diffuses into a liquid or solid to form a solution. The term sorption capture both processes, while desorption is the reverse of adsorption (Goyal et al., 2004). Adsorption onto activated carbon produced from agricultural wastes has a fast adsorption kinetics which makes it applicable for treatment of high strength and low volume phenolic wastewater (Tan et al., 2008). Activated carbon can be produced by carbonization and activation of the raw materials (Baseri et al., 2012).

Tan et al. (2008) studied the preparation of activated carbon from coconut husk using physico-chemical activation method which consists of potassium hydroxide $(\mathrm{KOH})$ treatment and carbon dioxide $\left(\mathrm{CO}_{2}\right)$ gasification which resulted in $191.73 \mathrm{mg} / \mathrm{g}$ for the uptake of 2,4,6-trichlorophenol and $20.16 \%$ of activated carbon yield. Hameed et al. (2009) investigated the effects of three preparation variable: activation temperature, activation time and potassium hydroxide $(\mathrm{KOH})$ - char impregnation ratio on the uptake of 2, 4, 6 - trichlorophenol and the activated carbon prepared from oil palm empty fruit butch which resulted in $17.96 \%$ activated carbon yield, Brunauer-Emmett-Teller (BET) surface area of $1141 \mathrm{~m}^{2} / \mathrm{g}$ and total pore volume of $0.6 \mathrm{~cm}^{3} / \mathrm{g}$. Wahi et al. (2009) investigated the ability of activated carbon prepared from oil palm empty fruit bunches by chemical and physical activation processes for the removal of mercury, copper and lead. It was noted that the produced adsorbents which was chemically activated with 
sodium hydroxide $(\mathrm{NaOH})$ could effectively remove mercury ( $\mathrm{Hg}$ (II)) and Lead $(\mathrm{Pb}$ (II)) ions from wastewater with percentage removal up to about $100 \%$. Bakhtiar et al. (2011) studied the used of oil palm shell for the preparation of activated carbon for the removal of 4-chloro-2methoxylphenol from aqueous solution using potassium trioxocarbonate (IV) $\mathrm{K}_{2} \mathrm{CO}_{3}$ for chemical activation. The effects of solution $\mathrm{pH}$, agitation time and initial concentration were evaluated. The Brunauer-Emmett-Teller (BET) surface area was $1571 \mathrm{~m}^{2} / \mathrm{g}$, the total pore volume was $0.8 \mathrm{~cm}^{3} / \mathrm{g}$ and the average pore diameter was $2.15 \mathrm{~nm}$. Adsorption data were fitted using a Langmuir isotherm, with a maximum monolayer adsorption capacity of $323.62 \mathrm{mg} / \mathrm{g}$. The adsorption kinetics was found to follow a pseudo-secondorder model.

Studies of the effect of process parameters for the carbonization of flamboyant pod bark using central composite design (CCD) under Response surface methodology (RSM) of the Design expert software are not well reported in the literature. Response surface methodology (RSM) is a collection of mathematical and statistical techniques that are useful for modeling and analysis of problems in which a response of interest is influenced by several variables. This method is suitable for fitting a quadratic surface and it helps to optimize the effective process parameters with a minimum number of experiments, as well as to analyze the interaction between the parameters. Generally, the CCD consists of a $2^{\mathrm{n}}$ factorial runs with $2 n$ axial runs and $n c$ center runs (six replicates) where $\mathrm{n}$ is the number of variables in the experiment. Depending on the number of factors involved, the total number of experiment needed will be given by

$$
\mathrm{N}=2^{\mathrm{n}}+2(\mathrm{n})+6
$$

The center points will be used to determine the experimental error and the reproducibility of the data. The axial points are at $( \pm \alpha, 0,0),(0, \pm \alpha$, $0),(0,0, \pm \alpha)$ where $\alpha$ is the distance of the axial point from the center point and make the design rotatable. The experimental sequence will be randomized in order to minimize the effect of uncontrolled factors. The response (Carbon yield Y) will be used to develop an empirical model which correlates the response to the five parameters of the adsorption process variables (Bokhari et al., 2012).

\section{Methodology \\ Materials}

Flamboyant (Delonix regia) pod bark was collected from the field of Ladoke Akintola University of Technology, Ogbomoso, Oyo State, Nigeria. 


\section{Methods}

The barks was mechanically cracked and crushed to reduce its size and increase its surface area. It was later washed with distilled water and sun-dried for seven days according to Amuda and Ibrahim (2006).

\section{Carbonization}

Carbonization was carried out according to the method adopted by Verla et al., (2012). Eleven (11 g) of flamboyant pod bark (FPB) was weighed into crucible and charged into the muffle furnace at selected temperature range between $\left(300-600{ }^{\circ} \mathrm{C}\right)$ and selected time range between (30-65 min) as shown in Table 1 . The process parameters (Temperature and time) were input into the central composite design (CCD) under the Response surface methodology (RSM) of Design Expert software to generate the number of experimental runs at random to determine the optimum yield.

Table 1: Factors Level Selected for Carbonization

\begin{tabular}{cccc}
\hline Factors & Units & & Level \\
\cline { 3 - 4 } & & Low & High \\
\hline Temperature & ${ }^{\circ} \mathrm{C}$ & 300 & 600 \\
Time & Min & 30 & 65 \\
\hline
\end{tabular}

\section{Yield}

The percentage yield of carbonized carbon was determined according to the method adopted by Ekpete and Horsfall, (2011) as shown in equation 2:

Yield $(\%)=\mathrm{W}_{\mathrm{c}} / \mathrm{W}_{\mathrm{o}} * 100$

where $\mathrm{W}_{\mathrm{c}}$ is the dry weight of final carbonized carbon and $\mathrm{W}_{\mathrm{o}}$ is the dry weight of precursor.

\section{Results and Discussion}

\section{Results of Response from Experimental Data}

Table 2 showed the experimental runs generated by central composite design for carbonization of flamboyant pod bark. The results showed that process parameters (temperature and time) has a significant effect on the yield obtained. It was observed that carbon yield decreases with increase in temperature and time. This is because an increase in temperature with time would increase the release of volatile matters due to dehydration and elimination reactions which result in decrease in carbon yield (Adinata et al., 2007). The maximum yield of $45.45 \%$ was obtained at run 1 at temperature of $300{ }^{\circ} \mathrm{C}$ and time 30 min while the minimum yield of $11.82 \%$ was obtained at run 11 at temperature of $600{ }^{\circ} \mathrm{C}$ and time of $65 \mathrm{~min}$. 
Table 2: Central Composite Design for Carbonization (Experimentation)

\begin{tabular}{cccc}
\hline Run & \multicolumn{2}{c}{ Ractor } & \multicolumn{2}{c}{$\begin{array}{c}\text { Respons } \\
\text { Tield } \\
(\%)\end{array}$} \\
\hline 1 & $\begin{array}{c}\text { Tempera } \\
\text { ture }\left({ }^{\circ} \mathrm{C}\right)\end{array}$ & Time & 45.45 \\
2 & 300 & 30 & 20.91 \\
3 & 600 & 30 & 30 \\
4 & 450 & 22.75 & 21.82 \\
5 & 450 & 47.50 & 18.36 \\
6 & 450 & 72.25 & 22.72 \\
7 & 450 & 47.50 & 13.64 \\
8 & 662.13 & 47.50 & 22.72 \\
9 & 237.87 & 47.50 & 19.09 \\
10 & 300 & 65 & 23.64 \\
11 & 450 & 47.50 & 11.82 \\
12 & 600 & 65 & 24.55 \\
13 & 450 & 47.50 & 23.64 \\
\hline
\end{tabular}

The maximum percentage yield obtained for the flamboyant pod bark investigated in this study compares well with yields from other agricultural wastes like pistachio $(20 \%)$, almond (32\%), hazelnut $(52 \%)$, walnut (57\%) as well as others (Kazemipour et al., 2008).

Table 3 shows the comparison of carbon yield obtained from various agricultural residues.

Table 3: Results of maximum percentage yield (\%) of char materials after carbonization.

\begin{tabular}{|c|c|c|}
\hline Agricultural waste & Yield (\%) & References \\
\hline FPB300-FPB600 & 45.45 & Present work \\
\hline Apricot stones & 18.2 & $\begin{array}{l}\text { Savova et al., } \\
(2001)\end{array}$ \\
\hline Net shell & 17.9 & $\begin{array}{l}\text { Savova et al., } \\
(2001)\end{array}$ \\
\hline Cherry stones & 11.2 & $\begin{array}{l}\text { Savova et al., } \\
\text { (2001) }\end{array}$ \\
\hline Grape seeds & 26.2 & $\begin{array}{l}\text { Savovaa et al., } \\
(2001)\end{array}$ \\
\hline
\end{tabular}

\section{Model Summary statistics}

Table 4 explained the model summary statistics of the yield obtained. The standard deviation showed the degree of deviation (errors) of the experimental values from the actual values while $\mathrm{R}^{2}$ reflects the efficiency of the experiments, adjusted $\mathrm{R}^{2}$ and Predicted $\mathrm{R}^{2}$ are the adjusted values and the values predicted by the Design Expert Software respectively. Quadratic model was suggested and cubic model was aliased. 
Table 4: Model Summary Statistics for Yield.

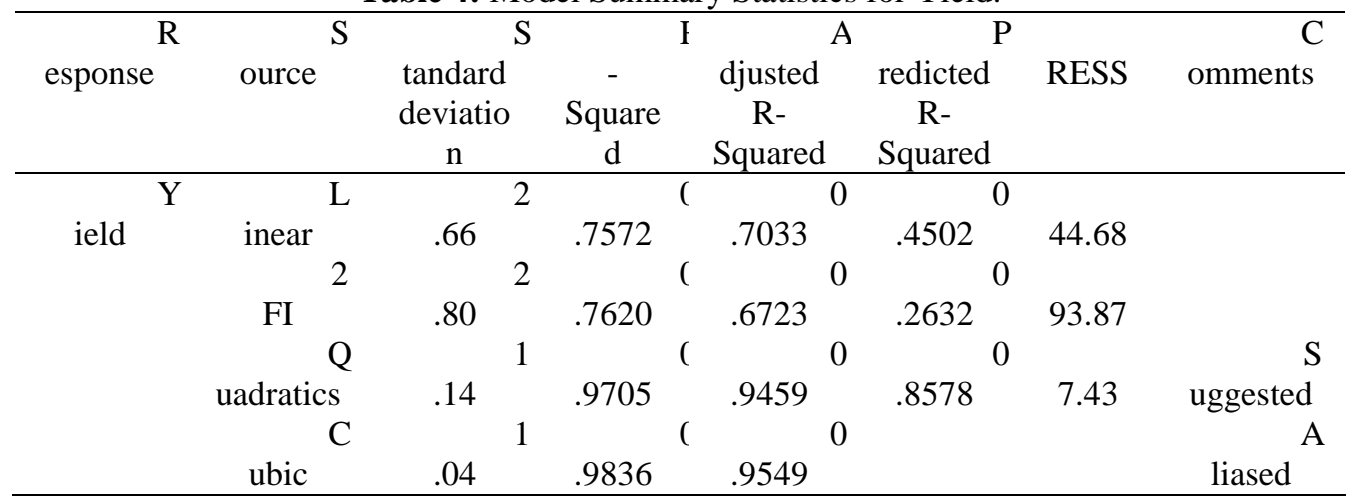

\section{Response for Analysis of Variance (ANOVA) of Yield}

ANOVA test was used to evaluate the statistical significance of the model equation. Table 6 showed the results of the analysis of variance of yield. The model F-value of 39.48 implies the model is significant and there is only a $0.02 \%$ chance that a "model F-value" this large could occur due to noise. Values of "Prob $>F$ " less than 0.0500 indicate the model term are significant and values greater than 0.1000 indicate the model term are not significant. $\mathrm{A}, \mathrm{B}$, and $\mathrm{A}^{2}$ are significant model terms. If there are many insignificant model terms (not counting those required to support hierarchy), model reduction may improve the model. The "lack of fit F-value" of 1.60 implies the lack of fit is not significant relative to the pure error. There is a $30.94 \%$ chance that a "lack of fit F-value" this large could occur due to noise. Standard deviation of 1.14 , mean of 21.08 , C.V of 5.40, PRESS of 37.43, R-Squared of 0.9705, Adjusted R-Squared of 0.9459, Predicted Rsquared of 0.8578 , Adequate Precision of 21.284 were obtained. "Adeq Precision" measures the signal to noise ratio and a ratio greater than 4 is desirable. The ratio of 21.284 indicates an adequate signal and this model can be used to navigate the design space.

Table 5: Analysis of Variance (ANOVA) of Yield

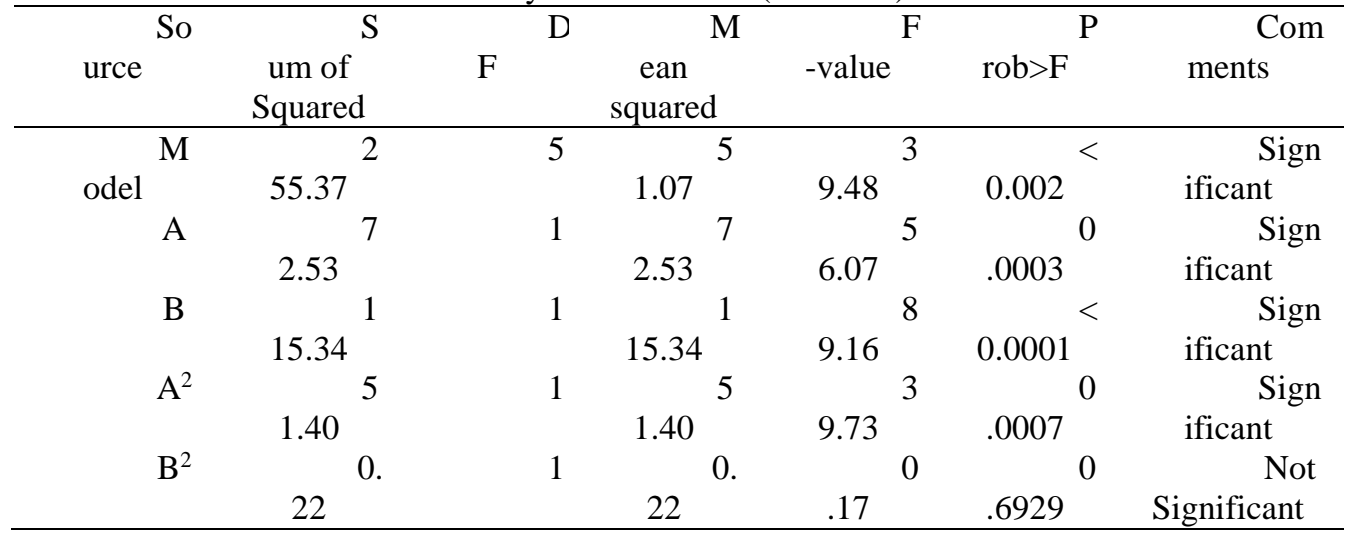




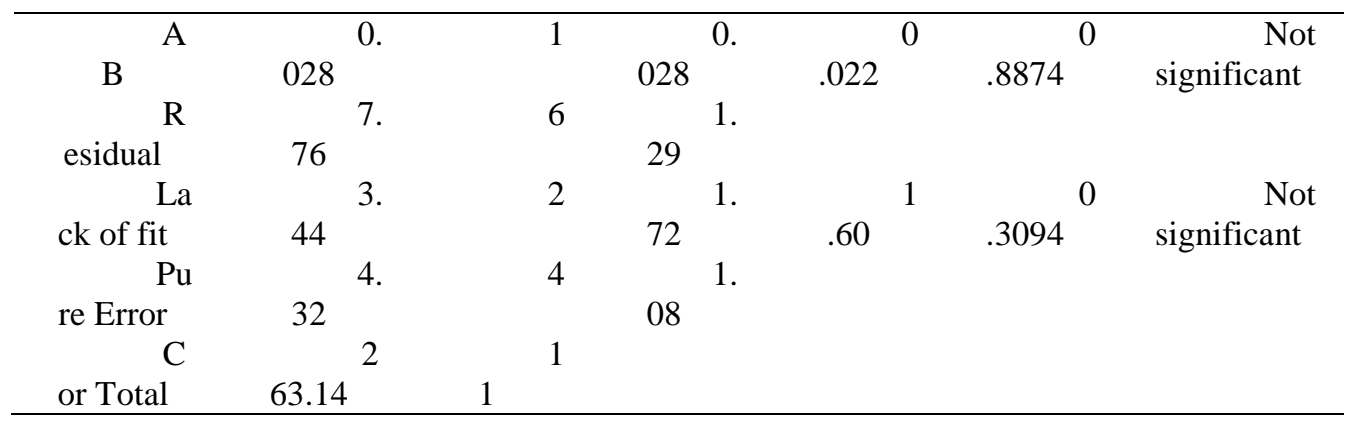

The final empirical model in terms of coded factor for the yield is given by equation 2 :

Yield $=+23.27-3.48 A-4.38 B-2.81 A^{2}+0.19 B^{2}+0.11 A B$

From the coded factors, it can be seen that $\mathrm{A}$ and $\mathrm{B}$ has negative coefficients which implies that they affects the yield of flamboyant pod bark (FPB) negatively.

\section{Diagnostic Case Studies}

\section{Diagnostic Case Studies for Yield}

Table 6 showed the result of the diagnostic case studies of the Yield, the actual values on the Table represent the amount of yield from flamboyant pod bark and the predicted value represent the standard generated by the software (DOE). The residual showed the closeness of the actual to the predicted value. Negative value of the residual indicates that the actual value is greater than the predicted value while the positive value implies than predicted value is greater than the actual value. Predicted value of zero means that the actual is tantamount to the standard value on which it comparison is based.

Table 6: Diagnostic Case Studies for Yield

\begin{tabular}{cccc}
\hline $\begin{array}{c}\text { Standard } \\
\text { Order }\end{array}$ & $\begin{array}{c}\text { Actual } \\
\text { value }\end{array}$ & $\begin{array}{c}\text { Predicted } \\
\text { value }\end{array}$ & Residual \\
\hline 1 & 23.64 & 22.95 & 0.69 \\
2 & 21.82 & 22.95 & -1.13 \\
3 & 24.55 & 22.95 & 1.60 \\
4 & 11.82 & 15.20 & -3.38 \\
5 & 18.36 & 13.77 & 4.59 \\
6 & 22.72 & 22.95 & -0.23 \\
7 & 13.64 & 15.06 & -1.42 \\
8 & 45.45 & 39.34 & 6.11 \\
9 & 30 & 32.13 & -2.13 \\
10 & 19.09 & 17.73 & 1.36 \\
11 & 23.64 & 22.95 & 0.69 \\
12 & 22.72 & 30.84 & -8.12 \\
13 & 20.91 & 19.54 & 1.37 \\
\hline
\end{tabular}




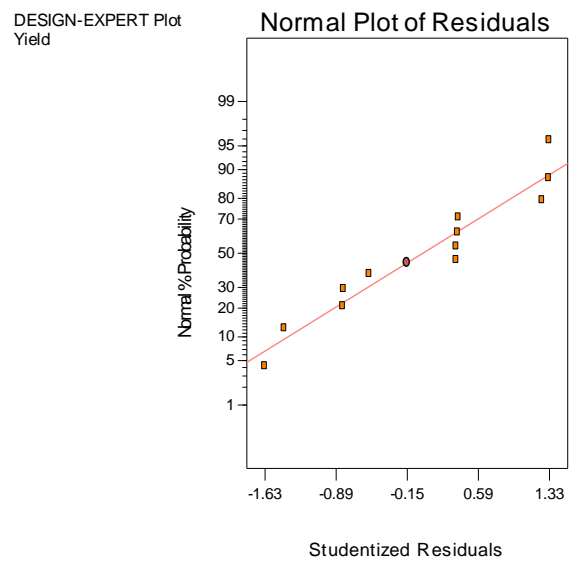

Figure 1: Yield Normal plot of Residual versus Actual

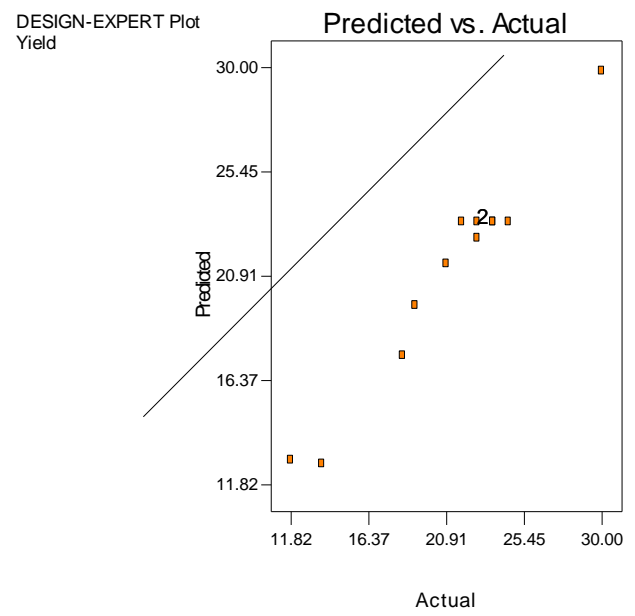

Figure 2: Yield plot of Predicted DESIGN-EXPERT Plot Yield
$\mathrm{X}=\mathrm{A}$ : Temperature
$\mathrm{Y}=\mathrm{B}$ : Time

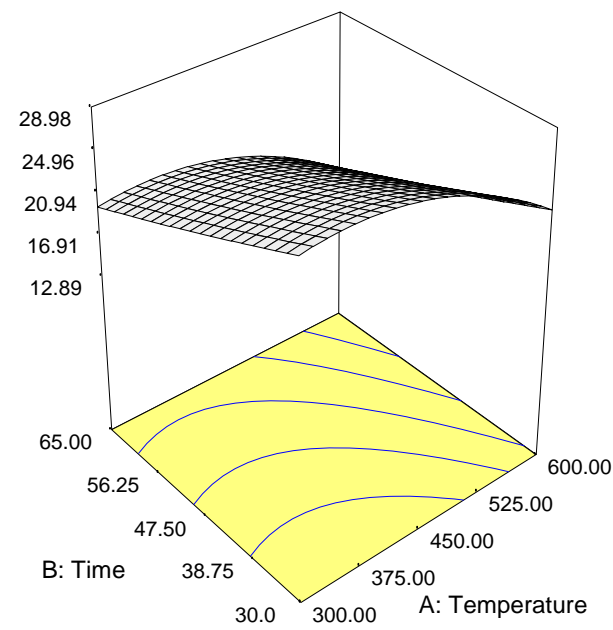

Figure 4: 3-D plot of Yield with and time

\section{Conclusion}

Central composite design under the Response Surface Methodology of Design Expert Software was successfully used to study the effects of process parameters (Temperature and time) for carbonization of flamboyant pod bark for the production of activated carbon for adsorption processes. An empirical model equation was developed for carbon yield as a function of parameters investigated. Quadratics model was developed to correlate the process parameter to the response. From the analysis of the response derived 
from the model, temperature and time were found to have the most significant effects on carbon yield.

\section{References:}

1. Adinata, D., Daud, W. M. and Aroua, M. K.. (2007). Preparation and characterization of activated carbon from palm shell by chemical activation with $\mathrm{K}_{2} \mathrm{CO}_{3}$. Bioresour. Technol., 98: 145-149.

2. Amuda, O. S. and Ibrahim, A. O. (2006). Industrial wastewater treatment using natural materials as adsorbent. African Journal of Biotechnology, 5(16): 1483-1487.

3. Ash, B., Satapathy, D., Mukherjee, P.S., Nanda, B., Gumaste, J.L. Mishra, B.K. Characterization and application of activated carbon prepared from coir pith. J.Sci.Ind.Res. 65: 1008-1012.

4. Bakhtiar, K., Hamad, A., Ahmad, M. D., Noor, S. and Rahim, A. (2011). Removal of 4-Chloro-2Methoxyphenol from Aqueous Solution by Adsorption to Oil Palm Shell Activated Carbon Activated with $\mathrm{k}_{2} \mathrm{CO}_{3}$. Journal of physical science, 22(1): 3955.

5. Baseri, J.R., Palanisamy, P.N. and Sivakumar, P. (2012). Preparation and characterization of activated carbon from Thevetia peruviana for the removal of dyes from textile wastewater. Journal of advances in Applied Science Research, 3(1): 377-383.

6. Bokhari, A., Yusuf, S. and Ahmad, M.M. (2012). Optimization of the Parameter that Affects the Solvent Extraction of Crude Rubber Seed Oil Using Response Surface Methodology (RSM). Recent Advances in Engineering, Proceeding of $3^{\text {rd }}$ European Conference of Chemical engineering, Paris, France, 2-4 ${ }^{\text {th }}$ December, 29-33.

7. Diao, Y., Walawender, W.P. and Fan, L.P. (2002). Activated carbons prepared from phosphoric acid activation of grain sorghum, Biores. Technol. 81: 45-52.

8. Ekpete, O. A. and Horsfall, M. (2011). Preparation and Characterization of Activated Carbon derived from Fluted Pumpkin Stem Waste (Telfairia occidentalis Hook F). Research Journal of Chemical Science, 1(3):10-17.

9. Goyal, M., Singh, S. and Bansal, R. (2004). Equilibrium and dynamics adsorption methylene blue from aqueous solutions by surface modified activated carbon. Journal of Carbon Science, 5: 170-179.

10. Hameed, B. H., Tan, A. W. and Ahmad, A. L. (2009). Preparation of oil palm empty fruit bunch-based activated carbon for removal of 2,4,6-trichlorophenol: Optimization using response surface methodology. Journal of Hazardous materials, 164: 1316-1324. 
11. Hu, Z. and Srinivasan, M.P. (1999). Preparation of high-surface-area activated carbons from coconut shell. Micropor. Mesopor. Mater. 27: 11-18.

12. Hu, Y.S, Malarvizhi, R. and Sulochana, N. (2009). Equilibrium Isotherm Studies of Methylene Blue Adsorption Activated Carbon Prepared from Delonix regia Pods. J. Envi prpte. scin. 3:111-116.

13. Kazemipour, M., Ansari, M. and Tajrobehkar, S. (2008). Removal of lead, cadium, zinc and copper from industrial wastewater by carbon developed from walnut, hazenut almond, pistachio shell and apricot stone. J. Hazard. Mater., 150: 322-327.

14. Krishnaiah, D., Anisuzzaman, S. M., Bono, A. and Sarbatly, R. (2013). Adsorption of 2,4,6-trichlorophenol (TCP) onto activated carbon. Journal of King Saud University-Science, 25: 251-255.

15. Martinez, J., Norland, S., Thingstad, T.F., Schroeder, D.C., Bratbak, G., Wilson, W.H. and Larsen, A. (2006). Variability in microbial population dynamics between similarly perturbed mesocosms. $J$. Plankton Res. 28: 783-791.

16. Savova, D., Apak, E., Ekinci, E, Yardim, F., Petrov, N., Budinova, T., Razvigorova, M.and Minkova, V. (2001). Biomass conversion to carbon adsorbents and gas. Biomass Bioenergy, 21: 133-142.

17. Sugumaran, P. and Seshadri S. (2009). Evaluation of selected biomass for charcoal production, J.Sci.Indu.Res. 68/8: 719-723.

18. Sugumaran, P., Susan, V. P., Ravichandran, P. and Seshadri, S. (2012). Production and characterization of activated carbon from banana empty bunch and Delonix regia fruit pod. Journal of sustainable and environment, 3: 125-132.

19. Suzuki, R.M., Andrade, A.D., Sousa, J.C. and Rollemberg, M.C. (2007) Preparation and characterization of activated carbon from rice bran, Biores. Technol. 98:1985-1991.

20. Tan, I.A.W., Hameed, B.H. and Ahmad, A.L. (2007). Equilibrium and kinetic studies on basic dye adsorption by oil palm fibre activated carbon, Chem. Eng. J. 127: 111-119.

21. Tan, I. A., Ahmad, A. L. and Hameed, B. H. (2008). Preparation of activated carbon from coconut husk ptimization study on removal of 2,4,6-trichlorophenol using response surface methodology. Journal of Hazardous Materials, 153: 709-717.

22. Tsai, W. T., Chang, C.Y. and Lee, S.L. (1997). Preparation and characterization of activated carbons from corn cob, Carbon 35, 1198-1200. 
23. Verla, A. W., Horsfall (Jnr), M., Verla, E. N., Spiff, A. I. and Ekpete, O. A. (2012). Preparation and Characterization of activated carbon from fluted pumkin (TELFAIRIA OCCIDENTALIS HOOK.F) SEED SHELL. Asian Journal of Natural and Applied science, 1(3): 39-50.

24. Wahi, R., Zainab, N. and Usun, J. (2009). Removal of Mercury, Lead and Copper from Aqueous Solution by Activated carbon of Palm oil Empty fruit Bunch. World Applied Sources Journal,

5: 34-91. 